\title{
CORRESPONDENCE.
}

\section{ON THE GROUPING OF ENDOWMENT ASSURANCES FOR VALUATION.}

To the Editor of the Journal of the Institute of Actuaries.

SeHR geEmRTer HerR,-Zu meinem grossen Bedauem bin ich der englischen Sprache nicht so weit mächtig, dass ich im Stande wäre einen längeren Brief zu schreiben, darum bitte ich Sie um Entschuldigung, wenn ich deutsch schreibe.

Es ist mir immer ein besonderes Vergnügen das Journal des Institute of Actuaries zu lesen, so war es auch diesmal der Fall, wo die April Nummer zwei hochinteressante Abhandlungen über die Berechnüng der Prämien-Reserven gemischter Versicherungen "Valuation of Endowment Assurances" brachte.

Da bei uns die gremischten Versicherungen schon seit Yahrzehnten eine sehr wichtige Rolle spielen, und da $70-75 \%$ der neuen Geschäfte nach dieser Combination abgeschlossen werden, mussten wir eine einfache Methode der Prämien-Reserve-Berechnung ersinnen, und da ich glaube, dass diese Methode für die englischen Fachcollegen von Interesse sein wird, erlaube ich mir, sie hier kurz zu erlaütern.

$$
\begin{aligned}
& { }_{k} \mathrm{~V}_{x \bar{n} \mid}=\mathrm{A}_{x+k \overline{n-n \mid}}-\mathbf{P}_{x \bar{n} \mid} \cdot \mathbf{a}_{x+k} \overline{n-k \mid} \quad\left[\mathbf{a}_{x \bar{n} \mid}=1+\mid n-1 a_{x}\right] \\
& =1-d \mathbf{a}_{x+\kappa} \overline{n-k}-\mathbf{P}_{x \bar{n}} \mid \mathbf{a}_{x+\kappa} \overline{n-n \mid} \\
& =1-d \mathbf{a}_{x+k}-\mathbf{P}_{x n} \mathbf{a}_{x+k}+\left[\mathbf{P}_{x n]}+d\right] \frac{\mathbb{N}_{x+n}}{\mathrm{D}_{x+k}} \\
& =\mathbf{A}_{x+\kappa}-\mathbf{P}_{m n[} \mathbf{a}_{x+k}+\frac{1}{\mathbf{D}_{x+k}} \mathbf{H}_{x n]} \text { wo } \mathbf{H}_{x \bar{j}}=\frac{\mathbb{N}_{x+n}}{\left.\mathbf{a}_{x n !}\right]}
\end{aligned}
$$

Die Gruppirnng der Versicherungen hat also nach dem Geburtsjahr zu erfolgen, damit für alle Versicherungen $x+\kappa$ denselben Werth habe, in diesen Gruppen können auch die lebenslanglichen Ver- 
sicherungen untergebracht werden. Das folgende Schema zeigt den Vorgang deutlich :-

Geburtsjahr $1800+u$.

\begin{tabular}{|c|c|c|c|c|c|c|}
\hline \multirow{2}{*}{$\begin{array}{l}\text { Policen- } \\
\text { Nummer }\end{array}$} & \multirow{2}{*}{$\begin{array}{l}\text { Versicherungs } \\
\text { Summe }\end{array}$} & \multirow{2}{*}{$\underbrace{\text { Versicherungs }}_{\text {Art }}$} & \multicolumn{2}{|c|}{ Jährdiche Prämé } & \multicolumn{2}{|c|}{ HILFSZAHE } \\
\hline & & & $\mathbf{P}$ & P.S & H & H.S \\
\hline & $\begin{array}{c}\mathrm{S}_{1} \\
\mathrm{~S}_{2} \\
\mathrm{~S}_{3} \\
\mathrm{~S}_{4} \\
\vdots \\
\vdots\end{array}$ & $\begin{array}{c}\mathbf{P}_{30} \\
\mathbf{A}_{32} \\
\mathbf{P}_{32: \overline{20}} \\
\mathbf{B}_{33: 151}: \overline{51} \\
\vdots \\
\vdots\end{array}$ & $\begin{array}{l}\mathbf{P}_{30} \\
\theta \\
\mathbf{P}_{32: 20} \\
\theta \\
\vdots \\
\vdots\end{array}$ & $\begin{array}{c}\mathrm{P}_{30} \cdot \mathrm{S}_{1} \\
\cdots \\
\mathrm{P}_{32: 20} \cdot \mathrm{S}_{3} \\
\cdots \\
\vdots \\
\vdots\end{array}$ & $\begin{array}{c}\theta \\
\theta \\
\mathbf{H}_{32 ; \overline{20}} \\
\text { K }_{33}: \overline{15 t} \\
\vdots \\
\vdots\end{array}$ & $\begin{array}{c}\ldots \\
\cdots \\
\mathrm{H}_{32: 20} \\
\mathrm{~K}_{33: 15]} \cdot \mathrm{S}_{2} \\
\vdots \\
\vdots\end{array}$ \\
\hline & $\Sigma(S)$ & & & $\Sigma(P . S)$ & & $\Sigma(H . S)$ \\
\hline
\end{tabular}

${ }^{*} \mathrm{~K}_{x \vec{n} \mid}=d \mathbb{N}_{x+n}$.

Prämien-Reserve am Ende des Kalender-Jahres $1800+w=$

$$
\begin{aligned}
& \frac{1}{2} \mathbf{S}(\mathbf{S}) \cdot\left[\mathrm{A}_{w-u}+\mathrm{A}_{w-u+1}\right]-\frac{1}{2} \mathbf{\Sigma}(\mathrm{P} . \mathbf{S})\left[\mathbf{a}_{w-u}+\mathbf{a}_{w-u+1}\right] \\
& \quad+\frac{1}{2} \Sigma(\text { H.S })\left(\frac{1}{\mathrm{D}_{w-u}}+\frac{1}{\mathbf{D}_{w-u+1}}\right)+\frac{1}{2} \Sigma(\text { P.S })
\end{aligned}
$$

Der bei uns herrschende Usus, als Eintritts-Alter (x) das Alter an dem dem Eintritts-Datum zunächst liegenden Geburtstag auzunehmen und die Dauer der Versicherung $(n)$ in vollen Versicherungs-Jahren zu bestimmen, macht es in vielen Fällen nothwendig, das Geburtsjahr zu korrigiren $u . z w$. derart, dass man bei der Gruppirung als Geburtsjahr die Differenz zwischen Eintritts-Jahr und Eintritts-Alter annimmt.

Diese Methode hat den Vorzug, dass sie sehr einfach und-wenn man die Voraussetzung, dass alle Versicherungen in der Mitte des Jahres abgeschlossen werden, gelten lässt--genau ist, weshalb sie sich wohl bald in der Praxis der englischen Actuare einburgern dürfte.

Will man den Werth der Kapitalien und den Werth der Prämien separat bestimmen, so muss man einfach $\mathrm{H}_{x \bar{n} \mid}$ in seine beiden Theile $\mathrm{K}_{x \bar{n}_{i}^{\prime}}=d \mathbb{N}_{x+n}$ und $\mathrm{K}_{x \bar{n}}^{\prime}=\mathrm{P}_{x \bar{n}} \mathbb{N}_{x+n}$ zerlegen, es ist dann pro Ende eines Versicherungs Jahres.

Werth der Kapitalien $=\mathbf{S}(\mathbf{S}) \cdot \mathbf{A}_{\boldsymbol{x}+\kappa}+\mathbf{\Sigma}\left(\mathrm{K}_{\boldsymbol{x} \bar{n} \mid} \cdot \mathbf{S}\right) \frac{1}{\mathrm{D}_{\boldsymbol{x}+\kappa}}$ und

Werth der Prämien $=\mathbf{\Sigma}(\mathbf{P}) \cdot \mathbf{a}_{x+k}-\mathbf{\Sigma}\left(\mathbf{K}_{x \overline{\mid} \mid}^{\prime} \cdot \mathbf{S}\right) \frac{1}{\mathrm{D}_{x+\kappa}}$, also

Prämien-Reserve $=\mathbf{S}(\mathbf{S}) \cdot \mathbf{A}_{x+\kappa}-\mathbf{S}(\mathrm{P}) \cdot \mathbf{a}_{x+\kappa}+\frac{1}{\mathrm{D}_{x+\kappa}}\left[\mathbf{S}\left(\mathbf{K}_{x \eta]} \cdot \mathbf{S}\right)\right.$

$$
+\mathbf{S}\left(\mathrm{K}_{x \bar{n} \cdot \cdot \mathrm{S})]}\right.
$$

Diese Methode kann auch auf alle zahlreichen anderen Versicherungs-Kombinationen, die bei uns üblich sind, angewendet werden, doch glaube ich, dass es überflüssig ist hierauf näher einzugehen. 
In der angenehmen Hoffnung, durch diese Mittheilung meinen Herren Collegen in England einen klienen Dienst erwiesen zu haben, bitte ieh Sie den Ausdruck meinen ganz besonderen Hochachtung zu genehmigen.

Ihr. ergebener,

\section{JULIUS ALTENBURGER,}

Viee-Präsident des Verbandes der oest.

Triest, 27 April 1898. und ungarischen Actuare.

\section{(Translation.)}

Honoured Sir,-To my great regret I am not suffieiently conversant with the English language to be in a position to write a long letter; I ask your indulgence, therefore, if I write in German.

It is always a special pleasure to me to read the Journal of the Institute of Actuaries, and this was the case again when the April number brought two highly interesting papers on the valuation of endowment assurances.

Seeing that among us endowment assurances have for some decades already played a very important part, and that 70 to 75 per-cent of the new business belongs to this class, it beeame necessary for us to devise a simple method of valuation, and as I believe that this method may be of interest to my English colleagues, I venture to explain it here briefly :-

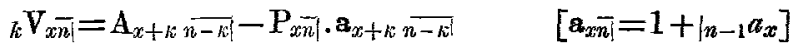

$$
\begin{aligned}
& =1-d \overline{\mathbf{a}_{x+\kappa} \overline{n-k} \mid}-\mathbf{P}_{x i \eta \overline{\mid}} \mid \mathbf{a}_{x+\kappa} \overline{n-k \mid}
\end{aligned}
$$

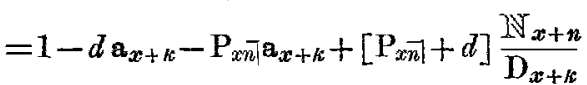

$$
\begin{aligned}
& =\mathrm{A}_{x+k}-\mathbf{P}_{x \bar{n} \mid} \mathbf{a}_{x+n}+\frac{1}{\mathrm{D}_{x+k}} \mathrm{H}_{x \bar{n}]} \text { where } \mathrm{H}_{x \bar{n} \mid}=\frac{\mathbb{N}_{x+n}}{\left.\mathbf{a}_{x \bar{n}}\right]}
\end{aligned}
$$

Grouping the Assurances now according to the year of birth and so bringing together all those for which $x+k$ bas the same value, we can bring the whole-life policies also into the group. The following scheme will show the procedure elearly-

Fear of Birth $1800+u$.

\begin{tabular}{|c|c|c|c|c|c|c|}
\hline \multirow{2}{*}{$\begin{array}{l}\text { Policy } \\
\text { No. }\end{array}$} & \multirow{2}{*}{$\underset{\text { Assured }}{\text { Sum }}$} & \multirow{2}{*}{$\begin{array}{l}\text { Class of } \\
\text { Assurance }\end{array}$} & \multicolumn{2}{|c|}{ Yearly Pramium } & \multicolumn{2}{|c|}{ ACXuiary No. } \\
\hline & & & $P$ & P.S & $\mathbf{H}$ & H.S \\
\hline & $\begin{array}{c}\mathbf{S}_{1} \\
\mathbf{S}_{2} \\
\mathbf{S}_{3} \\
\mathbf{S}_{4} \\
\vdots \\
\vdots\end{array}$ & $\begin{array}{c}\mathrm{P}_{30} \\
\mathrm{~A}_{32} \\
\mathrm{P}_{32: 20)} \\
\mathrm{A}_{35: 15} \\
\vdots \\
\vdots\end{array}$ & $\begin{array}{l}\mathbf{P}_{30} \\
\theta \\
\mathrm{P}_{32: \overline{201}} \\
\theta \\
\vdots \\
\vdots\end{array}$ & $\begin{array}{c}\mathbf{P}_{30} \cdot \mathbf{S}_{1} \\
\cdots \\
\mathbf{P}_{32: 20} \cdot \mathbf{S}_{8} \\
\because \\
\vdots \\
\vdots\end{array}$ & $\begin{array}{l}\theta \\
\theta \\
\mathbf{H}_{32}: \overline{20 \mid} \\
* \mathbf{K}_{33 ; 151} \\
\vdots \\
\vdots\end{array}$ & $\begin{array}{c}\cdots \\
\cdots \\
\mathbf{H}_{32: \overline{20}} \cdot \mathbf{S}_{3} \\
\mathbf{K}_{33} \cdot \overline{15} \cdot \mathbf{S}_{4} \\
\vdots \\
\vdots\end{array}$ \\
\hline & $\mathbf{s}(\mathrm{s})$ & & & $\mathbf{Z}(\mathbf{P} . \mathrm{S})$ & & $\mathbf{\Sigma}(\mathrm{H} . \mathrm{S})$ \\
\hline
\end{tabular}

$* \mathbf{K}_{x \bar{n} !}=d \mathbb{N}_{x+n}$. 
The reserve at the end of the calendar year $1800+w$ will be

$$
\begin{aligned}
& \frac{1}{2} \mathbf{\Sigma}(\mathrm{S}) \cdot\left[\mathrm{A}_{w-u}+\mathrm{A}_{w-u+1}\right]-\frac{1}{2} \mathbf{S}(\mathrm{P} . \mathrm{S})\left[\mathrm{a}_{w-u}+\mathbf{a}_{w-u+1}\right] \\
& \quad+\frac{1}{2} \mathbf{\Sigma}(\mathrm{H} . \mathrm{S})\left(\frac{1}{\mathrm{D}_{w-u}}+\frac{1}{\mathbf{D}_{w-u+1}}\right)+\frac{1}{2} \mathbf{\Sigma}(\mathrm{P} . \mathrm{S})
\end{aligned}
$$

The prevailing practice with us of taking the age at entry $(x)$ as the nearest age at the date of entry and to determine the duration of the assurance $(n)$ by integral policy years, makes it necessary, in many cases, to correct the year of birth in such a way as to take in the grouping for the year of birth the difference between the year of entry and the age at entry.

This method has the advantage that it is very simple, and (if we assume that all policies are effected on the average in the middle of the year) exact, on which account it may soon be adopted by English Actuaries.

If one wishes to determine the values of the sums assured and of the premiums separately, one need simply express $\mathbf{H}_{x \bar{n}}$ in its two parts, $\mathbf{K}_{x \bar{n}]}=d \mathbb{N}_{x+n}$ and $\mathbf{K}_{x \bar{n}}^{\prime}=\mathbf{P}_{x \bar{n} \mid} \mathbb{N}_{x+n}$. We then get, at the end of the Policy-year,

Value of Sum Assured $=\mathbf{S}(\mathbf{S}) \cdot \mathbf{A}_{x+\kappa}+\mathbf{Z}\left(\mathbf{K}_{x \cdot \bar{n}} \cdot \mathbf{S}\right) \frac{1}{\mathrm{D}_{x+\kappa}}$ and Value of Premiums $=\mathbf{\Sigma}(\mathbf{P}) \cdot \mathbf{a}_{x+k}-\mathbf{S}\left(\mathbf{K}_{x \bar{n}}^{\prime} \cdot \mathbf{S}\right) \frac{1}{\mathrm{D}_{x+k}}$, so that Reserve

$$
\begin{aligned}
& =\mathbf{S}(\mathrm{S}) \cdot \mathrm{A}_{x+\kappa}-\mathrm{Z}(\mathrm{P}) \cdot \mathrm{a}_{x+\kappa}+\frac{1}{\mathrm{D}_{x+\kappa}}\left[\mathrm{\Sigma}\left(\mathrm{K}_{x \bar{n}]} \cdot \mathrm{S}\right)\right. \\
& \left.+\mathbf{\Sigma}\left(\mathrm{K}_{x \bar{n} \cdot}^{\prime} \cdot \mathbf{S}\right)\right]
\end{aligned}
$$

This method ean also be applied to all the many other kinds of assurances which we grant, but I do not think it necessary to dwell on this further.

In the pleasant hope that by this communication I may be of some slight service to my colleagues in England, I beg you to accept the expression of my special regard.

Yours faithfully,

JULIUS ALTENBURGER,

Tiee-President of the Society of Austrian and Irungarian Actuaries.

Trieste, 27 April 1898.

[Many of our readers will probably remember the very similar formulas given by $\mathrm{Mr}$. Wm. D. Whiting, and published in the Transactions of the Actuarial Society of America, No. 12, p. 427.-Ev. J.I.A.] 